\title{
HUBUNGAN AKTIVITAS PROGRAM PENGELOLAAN PENYAKIT KRONIS DENGAN KEPATUHAN DIET PASIEN DIABETES MELITUS DI PUSKESMAS REJOSARI
}

\author{
Raviola $^{1}$, Wilda Muhsina ${ }^{2}$, Yeyen Gumayesty ${ }^{3}$ \\ Sekolah Tinggi Ilmu Kesehatan (STIKes) Hang Tuah Pekanbaru \\ raviola@htp.ac.id ${ }^{1}$, yeyenrangkuti@gmail.com²
}

\begin{abstract}
The Chronic Disease Management Program is a health care system and proactive approach that implemented in an integrated manner involving participants, First Level Health Facilities or we can call FLHF and Social Security Administering Bodies or BPJS health in the framework of health care for BPJS health participants with chronic diseases to achieve optimal quality of life with effective and efficient cost service. One of the chronic disease is Diabetes Mellitus. In Rejosari Puskesmas Pekanbaru many diabetes mellitus patients who do not follow diet activity and to find out about the implementation of PROLANIS. The purpose of this study was to determine the relationship between PROLANIS activity and dietary compliance toward diabetes mellitus patients at Rejosari. This study used quantitative with cross sectional design research. This research was conducted in June-August 2020. Population in this study amounted to 70 respondents of diabetes mellitus patients who visited the Rejosari. The data obtained through univariate and bivariate method with the chi-square test $(\alpha=$ 0.05). Beside that, the variables in this research are medical consultation, The Chronic Disease Management Program group education, SMS gateway reminder, home visit, health status monitoring. The results of the bivariate analysis showed that there is a significant relationship between medical consultation (0.017 $<a=0.05)$, group education $(\rho=0.028<\alpha=0.05)$, SMS reminders $(\rho=0.332<\alpha$ $=0.05)$, monitoring status $(\rho=0.009<\alpha=0.05)$, with dietary compliance. There are relationship between Chronic Disease Management Program Activities and Diet Compliance toward Diabetes Mellitus Patients at Rejosari Puskesmas.
\end{abstract}

Keywords $\quad$ : Diabetes Mellitus, Diet, The Chronic Disease Management Program

\begin{abstract}
ABSTRAK
Program pengelolaan penyakit kronis (PROLANIS) adalah suatu sistem pelayanan kesehatan dan pendekatan proaktif yang dilaksanakan secara terintegrasi yang melibatkan peserta, Fasilitas Kesehatan Tingkat Pertama dan BPJS kesehatan dalam rangka pemeliharaan kesehatan bagi peserta BPJS kesehatan yang menyandang penyakit kronis untuk mencapai kualitas hidup yang optimal dengan biaya pelayanan kesehatan yang efektif dan efisien. Salah satu jenis penyakit kronis adalah penyakit Diabetes Melitus. Masih banyak penderita diabetes melitus di Puskesmas Rejosari Kota Pekanbaru yang tidak mengikuti atau melakukan diet makanan dan untuk mengetahui tentang pelaksanaan aktivitas PROLANIS. Tujuan penelitian ini adalah untuk mengetahui hubungan aktivitas PROLANIS dengan kepatuhan diet pada pasien diabetes melitus di Puskesmas Rejosari. Jenis penelitian kuantitatif dengan desain cross sectional, Penelitian ini dilakukan pada bulan Juni-Agustus 2020. Populasi penelitian ini adalah semua penderita diabetes melitus yang berkunjung ke puskesmas jumlah sampel 70 responden. Analisis data dilakukan secara univariat dan bivariat dengan uji chisquare $(\alpha=0,05)$. variabel dalam penelitian ini yaitu konsultasi medis, edukasi kelompok peserta PROLANIS, reminder sms gateway, home visit, pemantauan status kesehatan. Hasil analisis bivariat didapatkan ada hubungan yang signifikan antara konsultasi medis $(0,017<a=0,05)$, Edukasi Kelompok ( $\rho=0,028<\alpha=0,05)$, Reminder SMS $(\rho=0,332<\alpha=0,05)$, Pemantauan Status ( $\rho$ $=0,009<\alpha=0,05)$, dengan Dengan kepatuhan Diet. Terdapat hubungan antara Aktivitas Program Pengelolaan Penyakit Kronis (Prolanis) Dengan Kepatuhan Diet Pada Pasien Diabetes Melitus Di Puskesmas Rejosari
\end{abstract}

Kata Kunci : Diabetes Melitus, Diet, PROLANIS 


\section{PENDAHULUAN}

Program pengelolaan penyakit kronis (PROLANIS) adalah suatu sistem pelayanan kesehatan dan pendekatan proaktif yang dilaksanakan secara terintegrasi yang melibatkan peserta, Fasilitas Kesehatan Tingkat Pertama (FKTP) dan Badan Penyelenggara Jaminan Kesehatan (BPJS) kesehatan dalam rangka pemeliharaan kesehatan bagi peserta BPJS kesehatan yang menyandang penyakit kronis untuk mencapai kualitas hidup yang optimal dengan biaya pelayanan kesehatan yang efektif dan efisien. Salah satu jenis penyakit kronis adalah penyakit Diabetes Mellitus (BPJS Kesehatan, 2014).

Diabetes melitus (DM) adalah penyakit gangguan metabolik yang terjadi secara kronis atau menahun karena tubuh tidak mempunyai hormon insulin yang cukup akibat gangguan pada sekresi insulin, hormon insulin yang tidak bekerja sebagaimana mestinya atau keduanya (Kemenkes RI, 2014).

Diet diabetes melitus adalah Pengaturan jumlah dan jenis makanan yang akan dikonsumsi setiap hari yang berguna untuk mengontrol kadar gula darah dalam mencegah dan memperlambat terjadinya komplikasi. Diet diabetes melitus bertujuan untuk membantu dalam memperbaiki kebiasaan makan dan olahraga untuk mengontrol metabolik (Tjokroprawiro, 2011).

Hasil penelitian yang dilakukan oleh Aditya Primahuda, Untung Sujianto (2016) terdapat hubungan yang signifikan antara kepatuhan mengikuti PROLANIS dengan stabilitas gula darah. Hal ini menunjukkan bahwa semakin tinggi tingkat kepatuhan maka semakin baik stabilitas gula darahnya. Berdasarkan 4 pilar prolanis mayoritas diabetisi tidak patuh terhadap edukasi (61\%), aktivitas fisik (56\%), dan pengobatan $(52,3 \%)$, sedangkan mayoritas diabetisi patuh terhadap diet $(90,2 \%)$.
Hasil Riset Kesehatan Dasar (RISKESDAS) Tahun 2018 menunjukkan bahwa prevalensi penyandang diabetes naik mejadi $8,5 \%$, dari $6,9 \%$ dan RISKESDAS (2018) menyebutkan bahwa kota Pekanbaru berada pada urutan nomor satu di Provinsi Riau yang menderita penyakit diabetes melitus sebanyak 2\%. Kota Pekanbaru memiliki 20 puskesmas, berdasarkan data dari Dinas Kesehatan Kota Pekanbaru tahun 2019 diketahui bahwa Puskesmas Rejosari Kota Pekanbaru memiliki jumlah pasien diabetes melitus nya paling banyak yaitu sebanyak 2268 pasien.

Kepatuhan terhadap diet sulit dicapai karena sering memerlukan perubahan jangka panjang dalam kebiasaan konsumsi dan metode persiapan makanan. (fadia, 2018). Tujuan penelitian ini adalah untuk mengetahui hubungan aktivitas PROLANIS dengan kepatuhan diet pada pasien diabetes melitus. Sehingga dapat diketahui kegiatan kegiatan PROLANIS apa saja yang dapat meningkatkan kepatuhan pada pasien DM. Jika sudah diketahui maka puskesmas atau instansi terkait dapat meningkatkan kegiatan tersebut sebagai bentuk kepatuhan pasien terhadap diet DM.

\section{METODE}

Jenis penelitian ini adalah analitik kuantitatif dengan desain penelitian cross sectional. Populasi dalam penelitian ini adalah semua penderita Diabetes Melitus yang berkunjung ke Puskesmas Rejosari Kota Pekanbaru bulan Juni sampai Agustus tahun 2020 sebanyak 269 penderita. Penelitiani ini dilakukan pada bulan JuniAgustus tahun 2020. Sampel diambil dengan teknik Non Random Sampling dengan teknik Accidental sampling dengan jumlah 70 responden.

Jenis data yang diambil terdiri dari data primer dan data sekunder. Pengumpulan data dilakukan dengan prosedur mencari data kasus Diabetes Melitus dengan melakukan penelusuran dokumen di Dinas 
Kesehatan Kota Pekanbaru, Puskesmas Rejosari tahun 2020 dan kuesioner tentang kepatuhan diet, konsultasi medis, edukasi kelompok peserta PROLANIS, reminder SMS geteway, home visit, pemantauan status kesehatan. Analisa data secara univariat bertujuan untuk menjelaskan atau

\section{HASIL}

Tabel 1. Distribusi Frekuensi Responden Berdasarkan Umur, Jenis Kelamin, Tingkat Pendidikan, Pekerjaan, Lama Menderita Diabetes Melitus di Wilayah Kerja Puskesmas Rejosari Kota Pekanbaru Tahun 2020

\begin{tabular}{|c|c|c|c|}
\hline Variabel & Kategori & $\begin{array}{l}\text { Frek } \\
\text { uensi }\end{array}$ & $\begin{array}{c}\text { Persentase } \\
(\%)\end{array}$ \\
\hline \multirow[t]{5}{*}{ Umur } & 26-35 Tahun & 1 & 1,4 \\
\hline & 36-45 Tahun & 4 & 5,7 \\
\hline & 46-55 Tahun & 23 & 32,9 \\
\hline & 56-65 Tahun & 34 & 48,6 \\
\hline & $>65$ Tahun & 8 & 11,4 \\
\hline Jenis & Laki-laki & 30 & 42,9 \\
\hline Kelamin & Perempuan & 40 & 57,1 \\
\hline \multirow[t]{4}{*}{ Pendidikan } & SD & 14 & 20,0 \\
\hline & SMP & 25 & 35,7 \\
\hline & SMA & 30 & 42,9 \\
\hline & $\mathrm{S} 1$ & 1 & 1,4 \\
\hline \multirow[t]{3}{*}{ Pekerjaan } & Bekerja & 23 & 32,9 \\
\hline & Tidak & 47 & 67,1 \\
\hline & Bekerja & & \\
\hline Lama & 1 & 3 & 4,3 \\
\hline Menderita & 2 & 6 & 8,6 \\
\hline Diabetes & 3 & 7 & 10,0 \\
\hline \multirow[t]{11}{*}{ Melitus } & 4 & 9 & 12,9 \\
\hline & 5 & 14 & 20,0 \\
\hline & 6 & 6 & 8,6 \\
\hline & 7 & 11 & 15,7 \\
\hline & 8 & 4 & 5,7 \\
\hline & 9 & 2 & 2,9 \\
\hline & 10 & 1 & 1,4 \\
\hline & 12 & 4 & 5,7 \\
\hline & 13 & 1 & 1,4 \\
\hline & 14 & 1 & 1,4 \\
\hline & 20 & 1 & 1,4 \\
\hline
\end{tabular}

Berdasarkan tabel 1 dapat diketahui responden terbanyak adalah responden dengan umur 56-65 tahun yang berjumlah 34 tahun $(48,6 \%)$. Jenis kelamin terbanyak adalah responden berjenis kelamin perempuan yang berjumlah 40 orang $(57,1 \%)$. Pendidikan terbanyak adalah responden dengan tingkat Pendidikan SMA mendeskripsikan karakteristik setiap variabel penelitian. Selanjutnya dilakukan analisa bivariat dilakukan untuk mengetahui hubungan dua variabel yaitu variabel independen dengan variabel dependen. Uji yang digunakan adalah uji chi square dengan derajat kepercayaan $(\alpha=0,05 \%)$.

yang berjumlah 30 orang (42,9\%). Pekerjaan terbanyak adalah responden tidak bekerja yang berjumlah 47 orang $(67,1 \%)$. Lama Menderita Diabetes Melitus terbanyak adalah responden dengan lama menderita diabetes melitus 5 tahun yang berjumlah 14 tahun $(20,0 \%)$.

Tabel 2. Hasil Analisis Univariat

\begin{tabular}{|c|c|c|}
\hline Variabel uji & $\begin{array}{l}\text { Frek } \\
\text { uensi }\end{array}$ & $\begin{array}{c}\text { Persentase } \\
(\%)\end{array}$ \\
\hline \multicolumn{3}{|l|}{ Kepatuhan Diet } \\
\hline 1. Patuh & 32 & 45,7 \\
\hline 2. Tidak Patuh & 38 & 54,3 \\
\hline Jumlah & 70 & $\mathbf{1 0 0 . 0}$ \\
\hline \multicolumn{3}{|l|}{ Konsultasi Medis } \\
\hline 1. Aktif & 34 & 48,6 \\
\hline 2. Tidak aktif & 36 & 51,4 \\
\hline Jumlah & 70 & 100.0 \\
\hline \multicolumn{3}{|l|}{ Edukasi Kelompok peserta } \\
\hline PROLANIS & 37 & 52,9 \\
\hline 1. Aktif & 33 & 47,1 \\
\hline 2. Tidak aktif & & \\
\hline Jumlah & 70 & 100.0 \\
\hline \multicolumn{3}{|l|}{ Reminder SMS Gateway } \\
\hline 1. Ada & 59 & 84,3 \\
\hline 2. Tidak Ada & 11 & 15,7 \\
\hline Jumlah & 70 & 100.0 \\
\hline \multicolumn{3}{|l|}{ Home Visit } \\
\hline 1. Ada & 0 & 0,0 \\
\hline 2. Tidak Ada & 70 & 100,0 \\
\hline Jumlah & 70 & 100.0 \\
\hline \multicolumn{3}{|l|}{ Pemantauan Status Kesehatan } \\
\hline 1. Aktif & 33 & 47,1 \\
\hline 2. Tidak Aktif & 37 & 52,9 \\
\hline Jumlah & 70 & $\mathbf{1 0 0 . 0}$ \\
\hline
\end{tabular}
responden yang tidak patuh dalam diet berjumlah 38 orang (54,3\%). Responden dengan konsultasi medis yang tidak aktif berjumlah 36 orang $(51,4 \%)$, responden dengan edukasi kelompok peserta PROLANIS yang tidak aktif berjumlah 33 orang $(47,1 \%)$, responden dengan tidak ada reminder SMS Gateway berjumlah 11 $(15,7 \%)$. Adapun seluruh responden tidak 
ada home visit berjumlah 70 orang (100\%) dan responden dengan pemantauan status Kesehatan yang tidak aktif berjumlah 37 orang $(52,9 \%)$.

\section{Hasil Bivariat}

Analisis bivariat digunakan untuk melihat hubungan antara variabel independen dan variabel dependen.
Berdasarkan analisis univariat, hanya 4 variabel yang dapat dilanjutkan untuk Analisa bivariat yaitu konsultasi medis, edukasi kelompok peserta PROLANIS,reminder SMS Gateway, dan pemantauan status Kesehatan, sedangkan variabel home visit tidak dapat dilanjutkan karen data yang homogen.

Hubungan Konsultasi Medis Dengan Kepatuhan Diet

Tabel 3. Hubungan Konsultasi Medis dengan Kepatuhan Diet Pada Pasien Diabetes Melitus di Wilayah Kerja Puskesmas Rejosari Kota Pekanbaru Tahun 2020

\begin{tabular}{|c|c|c|c|c|c|c|c|c|}
\hline \multirow{3}{*}{$\begin{array}{l}\text { Konsultasi } \\
\text { Medis }\end{array}$} & \multicolumn{6}{|c|}{ Kepatuhan Diet } & \multirow{3}{*}{ P value } & \multirow{3}{*}{ POR $95 \%$ CI } \\
\hline & \multicolumn{2}{|c|}{ Patuh } & \multicolumn{2}{|c|}{ Tidak Patuh } & \multicolumn{2}{|c|}{ Total } & & \\
\hline & $\mathbf{N}$ & $\%$ & $\mathbf{N}$ & $\%$ & $\mathbf{N}$ & $\%$ & & \\
\hline Aktif & 21 & 61,8 & 13 & 38,2 & 34 & 100 & \multirow{3}{*}{0,017} & \multirow{3}{*}{$\begin{array}{l}3,671 \\
(1,363-9,886)\end{array}$} \\
\hline Tidak Aktif & 11 & 30,6 & 25 & 69,4 & 36 & 100 & & \\
\hline Jumlah & 32 & 45,7 & 38 & 54,3 & 70 & 100 & & \\
\hline
\end{tabular}

Tabel 3. menunjukkan, dari 34 responden dengan konsultasi medis yang aktif, diketahui 21 orang $(61,8 \%)$ responden dengan diet yang patuh. Adapun dari 36 responden dengan konsultasi medis yang tidak aktif, diketahui 11 orang $(30,6 \%)$ responden dengan diet yang patuh.

Hubungan Edukasi Kelompok peserta PROLANIS Dengan Kepatuhan Diet

Tabel 4. Hubungan edukasi kelompok peserta PROLANIS dengan Kepatuhan Diet Pada Pasien Diabetes Melitus di Wilayah Kerja Puskesmas Rejosari Kota Pekanbaru Tahun 2020

\begin{tabular}{|c|c|c|c|c|c|c|c|c|}
\hline \multirow{3}{*}{$\begin{array}{l}\text { Edukasi } \\
\text { Kelompok }\end{array}$} & \multicolumn{6}{|c|}{ Kepatuhan Diet } & \multirow{3}{*}{ P value } & \multirow{3}{*}{ POR 95\% CI } \\
\hline & \multicolumn{2}{|c|}{ Patuh } & \multicolumn{2}{|c|}{ Tidak Patuh } & \multicolumn{2}{|c|}{ Total } & & \\
\hline & $\mathbf{N}$ & $\%$ & $\mathbf{N}$ & $\%$ & $\mathbf{N}$ & $\%$ & & \\
\hline Aktif & 22 & 59,5 & 15 & 40,5 & 37 & 100 & \multirow{3}{*}{0,028} & \multirow{3}{*}{$\begin{array}{l}3,373 \\
(1,252-9,087)\end{array}$} \\
\hline Tidak Aktif & 10 & 30,3 & 23 & 69,7 & 33 & 100 & & \\
\hline Jumlah & 32 & 45,7 & 38 & 54,3 & 70 & 100 & & \\
\hline
\end{tabular}

Tabel 4. menunjukkan, dari 37 responden dengan edukasi kelompok peserta PROLANIS yang aktif, diketahui 22 orang $(59,5 \%)$ responden dengan diet yang patuh. Adapun dari 33 responden dengan edukasi kelompok peserta PROLANIS yang tidak aktif, diketahui 10 orang $(30,3 \%)$ responden dengan diet yang patuh.

Hubungan Reminder SMS Gateway Dengan Dengan kepatuhan Diet

Tabel 5.Hubungan Reminder SMS Gateway dengan Kepatuhan Diet Pada Pasien

Diabetes Melitus di Wilayah Kerja Puskesmas Rejosari Kota Pekanbaru Tahun 2020

\begin{tabular}{|c|c|c|c|c|c|c|c|c|}
\hline \multirow{3}{*}{$\begin{array}{l}\text { Reminder } \\
\text { SMS } \\
\text { Gateway }\end{array}$} & \multicolumn{6}{|c|}{ Kepatuhan Diet } & \multirow{3}{*}{ P value } & \multirow{3}{*}{ POR $95 \%$ CI } \\
\hline & \multicolumn{2}{|c|}{ Patuh } & \multicolumn{2}{|c|}{ Tidak Patuh } & \multicolumn{2}{|c|}{ Total } & & \\
\hline & $\mathbf{N}$ & $\%$ & $\mathbf{N}$ & $\%$ & $\mathbf{N}$ & $\%$ & & \\
\hline Ada & 25 & 42,4 & 34 & 57,6 & 59 & 100 & & 0,420 \\
\hline Tidak & 7 & 63,6 & 4 & 36,4 & 11 & 100 & 0,332 & $(0,111-1,593)$ \\
\hline Jumlah & 32 & 45,7 & 38 & 54,3 & 70 & 100 & & \\
\hline
\end{tabular}


Tabel 5. menunjukkan, dari 59 responden dengan Reminder SMS Gateway, diketahui 25 orang $(42,4 \%)$ responden dengan diet yang patuh. Adapun dari 11 responden dengan tidak memiliki reminder SMS Gateway, diketahui 7 orang $(63,6 \%)$ responden dengan diet yang patuh.

Hubungan Pemantauan Status Kesehatan Dengan Kepatuhan Diet

Tabel 6. Hubungan Pemantauan Status Kesehatan dengan Kepatuhan Diet Pada Pasien Diabetes Melitus di Wilayah Kerja Puskesmas Rejosari Kota Pekanbaru Tahun 2020

\begin{tabular}{|c|c|c|c|c|c|c|c|c|}
\hline \multirow{3}{*}{$\begin{array}{l}\text { Pemantauan } \\
\text { Status } \\
\text { Kesehatan }\end{array}$} & \multicolumn{6}{|c|}{ Kepatuhan Diet } & \multirow{3}{*}{ P value } & \multirow{3}{*}{ POR 95\% CI } \\
\hline & \multicolumn{2}{|c|}{ Patuh } & \multicolumn{2}{|c|}{$\begin{array}{l}\text { Tidak } \\
\text { Patuh }\end{array}$} & \multicolumn{2}{|c|}{ Total } & & \\
\hline & $\mathbf{N}$ & $\%$ & $\mathbf{N}$ & $\%$ & $\mathbf{N}$ & $\%$ & & \\
\hline Aktif & 21 & 63,6 & 12 & 36,4 & 33 & 100 & \multirow{3}{*}{0,009} & \multirow{3}{*}{$\begin{array}{l}4,136 \\
(1,522-11,244)\end{array}$} \\
\hline Tidak aktif & 11 & 29,7 & 26 & 70,3 & 37 & 100 & & \\
\hline Jumlah & 32 & 45,7 & 38 & 54,3 & 70 & 100 & & \\
\hline
\end{tabular}

Tabel 6. menunjukkan, dari 33 responden dengan pemantauan status Kesehatan yang aktif, diketahui 21 orang $(63,6 \%)$ responden dengan diet yang patuh. Adapun dari 37 responden dengan pemantauan status Kesehatan yang tidak aktif, diketahui 11 orang $(29,7 \%)$ responden dengan diet yang patuh.

\section{PEMBAHASAN}

\section{Hubungan Konsultasi Medis dengan Kepatuhan Diet}

Berdasarkan uji statistik menggunakan Chi square diperoleh nilai $\mathrm{P}$ value $=0,017<$ a0,05, maka ha diterima dan ho ditolak, dapat disimpulkan bahwa ada hubungan antara konsultasi medis dengan kepatuhan diet. Dari hasil analisis diperoleh POR = $3,671>1$. Artinya responden dengan konsultasi medis yang tidak aktif lebih berisiko 3,6 kali dengan diet yang tidak patuh dibandingkan responden dengan konsultasi medis yang aktif.

Konsultasi medis merupakan salah satu program pengelolaan penyakit kronis dengan pendekatan proaktif yang dilaksanakan secara terintegrasi dan melibatkan peserta. Konsultasi medis dilakukan dengan cara konsultasi medis antara peserta PROLANIS dengan tim medis, jadwal konsultasi disepakati bersama antara peserta dengan Faskes Pengelola. Berdasarkan hasil penelitian terdapat $69,4 \%$ pasien diabetes yang tidak aktif melakukan konsultasi medis serta tidak patuh dalam diet. Hal ini menyebabkan Sebagian besar pasien dengan kadar gular darah tinggi kurang terkontrol dengan baik.

Hal ini sejalan dengan hasil penelitian Sekardini (2018) yang melakukan penelitian untuk melihat kualitas hidup peserta prolanis di Puskesmas Petaang 1 Kabupaten Badung Bali. Diketahui terdapat hubungan antara kurang nya konsultasi medis yang dilakukan pasien terhadap kepatuhan diet pada penderita diabetes.

Penelitian ini juga sejalan dengan penelitian yang dilakukan oleh Juhartini (2017) ada hubungan yang kuat antara pemberian konsultasi medis mengenai gizi dengan tingkat kepatuhan diet pada pasien DM berdasarkan hasil uji statistik menunjukkan ada hubungan yang kuat dengan kepatuhan diet dengan nilai yang mendekati angka -1 yaitu -0.68 , yang artinya jika frekuensi pemberian konsultasi ditingkatkan maka angka ketidakpatuhan diet akan menurun .

Menurut peneliti, pasien yang kurang aktif melakukan konsultasi medis sebagai upaya penanggulangan kadar gula darah menyebabkan pasien tidak melakukan 
kepatuhan diet. Hal ini menurut peneliti menyebabkan responden tidak mengontrol diet karena tidak mendapatkan informasi Kesehatan khususnya terkait kepatuhan diet. konsultasi medis dengan kepatuhan diet berperan penting dalam memperbaiki tingkat kadar gula darah sehingga dapat membantu proses penyembuhan penyakit diabetes melitus. Kepatuhan diet yang baik akan memperbaiki kebiasan makan dan minum seseorang yang menderita diabetes melitus sehingga dapat memperbaiki tingkat kadar gula darahnya. Responden yang aktif melakukan konsultasi medis akan mendapatkan pengetahuan tentang diabetes melitus, diet diabetes melitus dan masih banyak lagi. Dan responden yang tidak aktif melakukan konsultasi medis menunjukan kepatuhan dietnya hanya sebatas cukup patuh saja bukan pada tingkat patuh, hal ini dikarenakan tidak aktif melakukan konsultasi medis sehingga memungkinkan responden kurang patuh terhadap dietnya dalam penanganan penyakit diabetes melitus dikarena minimnya informasi yang didapat tentang diet diabetes melitus sehingga mempengaruhi kepatuhan dietnya.

Menurut peneliti sebaiknya petugas puskesmas lebih memberikan dukungan, motivasi dan semangat berupa pemberian reward bagi pasien yang aktif dan patuh supaya pasien tersebut aktif mengikuti konsultasi medis sehingga pasien dapat memperbaiki kepatuhan dietnya dan membantu memperbaki tingkat kadar gula darahnya.

\section{Hubungan Edukasi Kelompok peserta PROLANIS dengan Kepatuhan Diet}

Berdasarkan uji statistik menggunakan Chi square diperoleh nilai $\mathrm{P}$ value $=0,028<$ $\mathrm{a} 0,05$, maka ha diterima dan ho ditolak, dapat disimpulkan bahwa ada hubungan antara edukasi kelompok peserta PROLANIS dengan kepatuhan diet. Dari hasil analisis diperoleh POR $=3,373>1$. Artinya responden dengan edukasi kelompok peserta PROLANIS yang tidak aktif lebih berisiko 3,3 kali dengan diet yang tidak patuh dibandingkan responden dengan edukasi kelompok peserta PROLANIS yang aktif.

Edukasi kelompok peserta PROLANIS merupakan salah satu program pengelolaan penyakit kronis kegiatan untuk meningkatkan pengetahuan kesehatan dalam upaya memulihkan penyakit dan mencegah timbulnya kembali penyakit serta meningkatkan status kesehatan bagi peserta PROLANIS.

Edukasi kelompok peserta PROLANIS telah dilakukan di Puskesmas Rejosari dengan jadwal minimal satu kali perbulan setiap tanggal 18. Edukasi kelompok peserta PROLANIS dilakukan oleh petugas Prolanis memberikan edukasi dengan materi yang beragam, antara lain mengenai materi penyakit dia, komplikasinya, pentingnya olahraga, mengenai gizi lansia, dan gaya hidup dan edukasi-edukasi lain yang berkenaan dengan peningkatan kualitas hidup. Kegiatan edukasi dilakukan secara rutin dengan tujuan meningkatkan pengetahuan peserta, karena pendidikan kesehatan sangat efektif dalam meningkatkan pengetahuan, dapat memperbaiki manajemen diri, dan mengendalikan gaya hidup yang dapat merugikan pasien.

Berdasarkan hasil penelitian diketahui terdapat $69 \%$ peserta yang tidak aktif dalam diskusi kelompok dan tidak patuh diet. Menurut Becker dan pratt dalam Niven (2013) faktor yang memyebabkan ketidakpatuhan mengikuti edukasi antara lain keyakinan, sikap, dukungan keluarga, dan kepribadian. Mayoritas ketidakpatuhan diabetisi dalam melaksanakan aktivitas fisik karena responden ditempat kerja jarang berdiri, di waktu luang jarang bersepeda, memiliki pekerjaan yang ringan, aktivitas fisik di waktu luang jarang dilakukan.

Hal ini sejalan dengan hasil penelitian Primahuda (2016) yang melakukan penelitian untuk mengetahui Hubungan Antara Kepatuhan Mengikuti Program Pengelolaan Penyakit Kronis (PROLANIS) BPJS Dengan Stabilitas Gula Darah Pada 
Penderita Diabetes Melitus Di Puskesmas Babat Kabupaten Laomgan diketahui terdapat hubungan antara edukasi kelompok dengan tingkat kepatuhan diet pada pasien.

Hasil penelitian ini juga sejalan dengan penelitian yang dilakukan oleh Fadia (2018) yang menjelaskan bahwa semakin lama seorang penderita diabetes menjadi anggota dari PROLANIS dan mendapatkan edukasi yang banyak maka mereka semakin meningkatkan kepatuhan diet.

Menurut peneliti, edukasi kelompok peserta PROLANIS pada pasien diabetes bermanfaat dalam upaya meningkatkan pengetahuan kesehatan guna memulihkan penyakit dan mencegah timbulnya kembali penyakit serta meningkatkan status kesehatan bagi peserta PROLANIS. Edukasi kelompok peserta PROLANIS dengan kepatuhan diet merupakan salah satu upaya penyesuaian atau pembelajaran kepada masyarakat agar mau melakukan tindakan-tindakan untuk memelihara atau mengatasi masalah-masalah, dan meningkatkan kesehatanya. Edukasi kelompok peserta PROLANIS bagi pasien diabetes melitus berhubungan dengan perilaku pasien dalam melakukan pengendalian kadar glukosa darah agar tetap stabil.

Menurut peneliti, diharapkan pasien diabetes melitus mengikuti edukasi kelompok peserta PROLANIS supaya pasien diabetes melitus mampu melakukan pengendalian kadar gula darah dengan baik.

\section{Hubungan Reminder SMS Gateway dengan Kepatuhan Diet}

Berdasarkan uji statistik menggunakan Chi square diperoleh nilai $\mathrm{P}$ value $=0,332>$ $\mathrm{a} 0,05$, maka ha ditolak dan ho diterima, dapat disimpulkan bahwa tidak ada hubungan antara reminder SMS Gateway dengan kepatuhan diet. Dari hasil analisis diperoleh $\mathrm{POR}=0,420<1$. Artinya reminder sms Gateway bukan merupakan factor risiko kepatuhan diet.

Reminder SMS Gateway adalah kegiatan untuk memotivasi peserta untuk melakukan kunjungan rutin kepada Faskes Pengelola melalui peringatan jadwal konsultasi ke Faskes Pengelola tersebut sasaran dari hal ini adalah tersampaikannya reminder jadwal konsultasi peserta ke masing-masing Faskes Pengelola.

Reminder SMS Gateway ini merupakan salah satu kegiatan wajib dari PROLANIS dengan harapan setelah melakukan reminder, peserta akan termotivasi mengikuti kegiatan PROLANIS secara rutin. Petugas PROLANIS mengatakan telah melakukan rekapitulasi nomor handphone para peserta untuk memudahkan melakukan sms. Petugas mengatakan bahwa hambatan dalam melakukan reminder adalah $10 \%$ disebabkan karena biaya dan $50 \%$ karena tidak memiliki layanan teknologi baik untuk telfon maupun pesan.

Berdasarkan hasil penelitian diketahui terdapat 59 responden yang memiliki reminder SMS Gateway, dan 42,4\% diantaranya memiliki kepatuhan diet. Hal ini menunjukkan pelaksanaan prolanis dengan Reminder SMS Gateway sudah berjalan baik. Namun tidak semua pasien yang menerima reminder SMS Gateway mengikuti kegiatan PROLANIS.

Hal ini sejalan dengan hasil penelitian Primahuda (2016) yang melakukan penelitian untuk mengetahui Hubungan Antara Kepatuhan Mengikuti Program Pengelolaan Penyakit Kronis (PROLANIS) BPJS Dengan Stabilitas Gula Darah Pada Penderita Diabetes Melitus Di Puskesmas Babat Kabupaten Laomgan diketahui tidak terdapat hubungan antara reminder SMS Gateway dengan kepatuhan diet. Hal ini menunjukkan reminder SMS Gateway sudah berjalan dengan baik.

Penelitian ini sejalan dengan penelitian yang dilakukan oleh Ichwan (2018) yang menjelaskan bahwa sms Gateway sebagai reminder pasien diabetes untuk melakukan diet sehingga mereka lebih patuh jika diingatkan menggunakan SMS Gateway.

Menurut peneliti, Reminder SMS Gateway sebagai upaya dalam mengingatkan pasien dalam hal jadwal 
konsultasi pasien. Namun meskipun Reminder SMS Gateway sudah berjalan dengan baik, tidak membuat pasien memiliki kepatuhan. Banyak faktor yang menyebabkan pasien tidak memiliki kepatuhan diet seperti kurangnya dukungan keluarga, keyakinan dan sikap diri.

Menurut peneliti, seharusnya kegiatan reminder SMS Gateway harus dilakukan untuk semua kegiatan apapun yang menyangkut PROLANIS baik yang telah terjadwal maupun tidak, ini akan meningkatkan jumlah kunjungan. Mengenai feedback sms reminder Gateway untuk mendorong kepatuhan pasien mendapatkan respon bahwa pasien merasa kegiatan reminder itu berguna, mudah digunakan dan tidak menimbulkan masalah atau kerusakan.

\section{Hubungan Home Visit dengan Kepatuhan Diet}

Berdasarkan hasil Univariat diperoleh seluruh responden tidak ada home visit berjumlah 70 orang (100\%) sehingga home visit tidak dapat dilanjutkan karena data yang homogen. Home visit adalah kegiatan pelayanan kunjungan kerumah peserta PROLANIS untuk pemberian informasi atau edukasi kesehatan diri dan lingkungan bagi peserta PROLANIS dan keluarga.

Puskesmas Rejosari Kota Pekanbaru tidak melakukan home visit. Padahal kegiatan ini merupakan salah satu kegiatan dari PROLANIS, dalam buku panduan PROLANIS BPJS (2015) dikatakan bahwa kegiatan home visit adalah kegiatan pelayanan kunjungan ke rumah peserta PROLANIS untuk pemberian informasi atau edukasi kesehatan diri dan lingkungan bagi peserta dan keluarga. Puskesmas Rejosari tidak melaksanakan kegiatan home visit karena, Waktu yang tidak memungkinkan atau waktu yang terbatas. Kendala lain yang sering ditemui oleh petugas kesehatan dalam melakukan home visit adalah adanya tugas rangkap dari Puskesmas yang menjadi faktor penghambat. Peserta PROLANIS masih aktif atau mampu untuk berkunjung sendiri ke Puskesmas sehingga petugas merasa tidak perlu melakukan kunjungan ke rumah pasien.

Penelitian ini sejalan dengan penelitian yang dilakukan oleh Arifin (2015) yang menjelaskan ada hubungan antara home visit dan dukungan keluarga terhadap pelaksanaan diet pada pasien DM. Hasil penelitian ini juga sejalan dengan hasil penelitian yang dilakukan oleh Argi (2020) yang menyatakan ada hubungan yang bermakna antara home visit dan dukungan keluarga dengan kepatuhan diet $(\mathrm{p}=0,038$; $\mathrm{p}>\alpha)$.

\section{Hubungan Pemantauan Status Kesehatan dengan Kepatuhan Diet}

Berdasarkan uji statistik menggunakan Chi square diperoleh nilai $\mathrm{P}$ value $=0,009<$ a0,05, maka ha diterima dan ho ditolak, dapat disimpulkan bahwa ada hubungan antara pemantauan status kesehatan dengan kepatuhan diet. Dari hasil analisis diperoleh $\mathrm{POR}=4,136>1$. Artinya responden dengan pemantauan status Kesehatan tidak aktif lebih berisiko 4,1 kali dengan diet yang tidak patuh dibandingkan responden dengan pemantauan status Kesehatan.

Pemantauan status Kesehatan merupakan upaya yang dilakukan Puskesmas kepada peserta terdaftar yang meliputi pemeriksaan tekanan darah dan pemeriksaan kadar gula darah oleh tenaga kesehatan. Petugas melakukan pencatatan di buku pemantauan status kesehatan peserta. Mencatat pemantauan status kesehatan peserta sangat bermanfaat bagi petugas dan penderita diabetes melitus sebagai penghubungnya dan implentasi alur pelayanan terintegrasi dan buku pemantauan kesehatan penderita diabetes melitus dan dapat meningkatkan mutu pelayanan di Puskesmas Rejosari Kota Pekanbaru.

Berdasarkan hasil penelitian diketahui terdapat $70,3 \%$ pasien yang tidak aktif dalam pemantauan status Kesehatan dan tidak memiliki kepatuhan diet. Ketika pasien diabetes tidak melakukan 
pemantauan status Kesehatan secara teratur menyebabkan tidak terkontrolnya kadar gula darah, bila keadaan tersebut diatas tidak segera diobati, maka akan timbul gejala yang disebabkan oleh kemunduran kerja insulin.

Hal ini sejalan dengan hasil penelitian Risnasari (2014) yang melakukan penelitian untuk mengetahui Hubungan Tingkat Kepatuhan Diet Pasien Diabetes Melitus Dengan Munculnya Komplikasi Di Puskesmas Pesantren Iikota Kediri, diketahui terdapat hubungan antara pemantauan status kesehatan dengan kepatuhan diet.

Hasil penelitian ini juga sejalan dengan penelitian yang dilakukan oleh Yulia (2015) yang menyatakan pemantauan status kesehatan ada hubungan yang signifikan dengan kepatuhan diet pada pasien DM ( $p$ value $=0,021$ ).

Menurut peneliti, upaya pemantauan status Kesehatan penting dilakukan bagi pasien diabetes. Upaya ini berguna dalam mengontrol kadar gula bagi pasien. Pemantauan status Kesehatan dapat berjalan baik jika optimalnya peran petugas Kesehatan dalam melakukan berbagai kegiatan dalam PROLANIS.

Sebaiknya aktivitas pemantauan status Kesehatan harus di tingkatkan lagi oleh petugas dengan cara mendatangi ke rumah pasien diabetes melitus yang sudah lebih dari 3 kali tidak melakukan pemantauan status kesehatannya.

\section{KESIMPULAN}

Ada hubungan antara konsultasi medis, edukasi kelompok, reminder SMS Gateway, pemantauan status kesehatan dengan kepatuhan diet pada pasien diabetes melitus di Puskesmas Rejosari kota Pekanbaru tahun 2020 dan Berdasarkan hasil Univariat diperoleh seluruh responden tidak ada home visit berjumlah 70 orang (100\%) sehingga home visit tidak dapat dilanjutkan karena data yang homogen.

\section{UCAPAN TERIMAKASIH}

Terima kasih kepada kepala Puskesmas Rejosari Kota Pekanbaru yang telah memberi izin kepada tim peneliti untuk melaksanakan penelitian, kepada responden yang telah bersedia dan meluangkan waktunya mengisi kuesioner, serta seluruh pihak-pihak terkait yang telah banyak memberikan bantuan dan dukungan dalam pelaksanaan penelitian yang penulis tidak dapat sebutkan satu persatu.

\section{DAFTAR PUSTAKA}

Arifin (2015). Hubungan Dukungan Keluarga Dengan Kepatuhan Diet diabetes Melitus Tipe 2 Di Poli Penyakit Dalam Rsup Dr. Soeradji Tirtonegoroklaten. Vol. II Nomor 2 September 2015 - Jurnal Keperawatan Respati.

Ayu, Fadia (2018). Hubungan Lama Kepesertaan Prolanis Dengan Tingkat Pengetahuan Gizi Dan Kepatuhan Diet Pasien Diabetes Mellitus Di Puskesmas Gilingan Surakarta. Jurnal Dunia Gizi, Vol. 1, No. 2, Desember 2018: 101-111.

BPJS Kesehatan (2014). Panduan Klinis Prolanis BPJS Kesehatan.Jakarta: BPJS. Diakses tanggal 13 Juli 2020

FKUI (2007). Hidup Sehat Dengan Diabetes. Jakarta: FKUI

IDF (2017). Diabetes Atlas Eighth Edition. Diakses tanggal 4 Februari 2020

Juhartini (2017). Hubungan Antara Frekuensi Pemberian Konsultasi Gizi Dengan Kepatuhan Diet Dan Kadar Gula Darah Pada Diabetisi Tipe 2 Di Unit Pelayanan Terpadu Diabetes Melitus Center Kota Ternate. Jurnal Riset Kesehatan. Vol 6. No. 2

Kemenkes RI (2014). Profil Kesehatan Indonesia 2014. Diakses tanggal 3 Februari 2020

Kementerian Kesehatan (2015). Tentang Pusat Kesehatan Masyarakat. Diakses tanggal 19 Februari 2020

Peraturan Menteri Kesehatan (2014). Permenkes 75 Tahun 2014. Diakses tanggal 19 Februari 2020

Primahuda, A, Sujianto, U (2016). Hubungan Antara Kepatuhan Mengikuti Program Pengelolaan Penyakit Kronis (Prolanis) 
Bpjs Dengan Stabilitas Gula Darah Pada Penderita Diabetes Melitus Di Puskesmas babat. Jurnal Kesehatan Masyarakat, 6(2), pp. 83-91.

RISKESDAS (2018). Badan Penelitian dan Pengembangan Kesehatan Kementerian Kesehatan RI. Diakses tanggal 3 Februari 2020

Sekardini, NLP. (2018). Gambaran kualitas hidup peserta prolanis di puskesmas petang 1 kabupaten badung bali. MEDISAINS: Jurnal Ilmiah Ilmu-ilmu Kesehatan, Vol 16 No 3, DESEMBER 2018. Halaman 132

Syamsiyah, N (2017). Berdamai Dengan diabetes. Jakarta: Tim Bumi Medika

Soegondo (2009). Penatalaksanaan Diabetes Melitus Terpadu. Jakarta: Balai Penerbit FKUI

Sugiyono (2019). Statistika Untuk Penelitian. Bandung: Alfabeta CV

Risnasari (2014). Rahasia Herbal Penyembuh Diabetes. Yogyakarta: Bentang Pustaka

Tjokroprawiro, A (2011). Panduan Lengkap Pola Makan Untuk Penderita Diabetes. Jakarta: Gramedia Pustaka Utama

Virgona. Argi (2020). Hubungan antara Dukungan Keluarga dengan Kepatuhan Diet pada Penderita Diabetes Mellitus Tipe 2. Jurnal Ilmu Keperawatan Medikal Bedah 3 (1), Mei 2020, 1-76

WHO (2014). Diabetes. Diakses tanggal 3 Februari 2020

WHO (2016). Diabetes Melitus. Diakses tanggal 3 Februari 2020

Yulia (2015). Faktor-Faktor Yang Mempengaruhi Kepatuhan Dalam Menjalankan Diet Pada Penderita Diabetes Mellitus Tipe 2. Skripsi : UNNES. 